RESEARCH ARTICLE

\title{
Assessment of hydrogeological scenario in a cross-section from Anamaduwa to Kalpitiya in Northwest Sri Lanka
}

\section{B.N.B. Wickramasinghe, H.A.H. Jayasena*, K.V.G.S. Perera and R.R.G.R. Rajapakse}
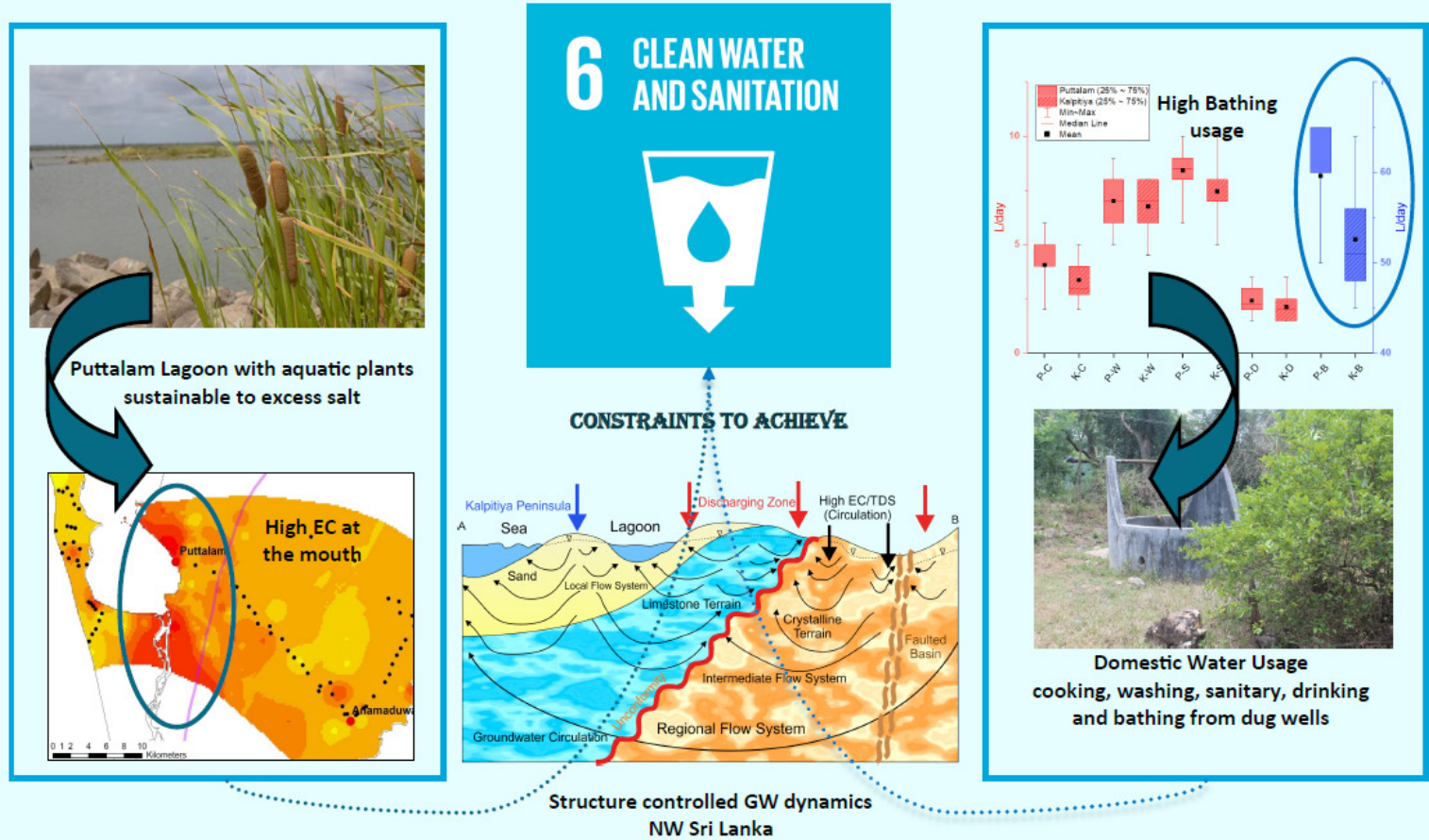
NW Sri Lanka

\section{Highlights}

- Water quality is poor in sandy, limestone, and hard rock aquifers in NW Sri Lanka

- Restricted circulation due to faults and unconformity resulted in EC/TDS increase

- Practice Managed Aquifer Recharge (MAR) to prevent saltwater intrusions

- Strict policy-controlled groundwater development is needed to achieve SDG 6

- Advanced modeling is expected to properly frame the GW occurrence and movement 
RESEARCH ARTICLE

\title{
Assessment of hydrogeological scenario in a cross-section from Anamaduwa to Kalpitiya in Northwest Sri Lanka
}

\author{
B.N.B. Wickramasinghe ${ }^{1}$, H. A. H. Jayasena ${ }^{2, *}$, K.V.G.S. Perera ${ }^{3}$ and R.R.G.R. Rajapakse ${ }^{4}$ \\ ${ }^{1}$ Geological Survey and Mines Bureau, 569, Epitamulla Road, Pitakotte, 10100, Sri Lanka. \\ ${ }^{2}$ Department of Geology, University of Peradeniya, Peradeniya 20400, Sri Lanka. \\ ${ }^{3}$ School of Science and the Environment, Memorial University of Newfoundland, Corner Brook, A2H 5G4, NL, Canada. \\ ${ }^{4}$ Water Resources Board, 2A, Hector Kobbekaduwa Mawatha, Colombo 00700, Sri Lanka.
}

Received: 19/06/2020; Accepted: 05/02/2021

\begin{abstract}
The hydrogeological regime covering a section passing from Anamaduwa to the Kalpitiya peninsula in northwest Sri Lanka was examined to understand the groundwater flow across the metamorphic and sedimentary rock terrains. The study was conducted as a hydrogeological survey based on a structured questionnaire $(n=82)$ on the consumption, water level fluctuation, and water supply, supplemented by field examination of shallow dug $(\mathrm{n}=20)$ and tube wells $(\mathrm{n}=62)$. In Kalpitiya the average water level fluctuation was $3.44 \mathrm{~m}$ (vary from 2.95 to $6.39 \mathrm{~m}$ ) while it was $6.27 \mathrm{~m}$ (vary from 2.25 to $8.52 \mathrm{~m}$ ) in the Anamaduwa-Puttalam area. The drinking water supply in Kalpitiya was 24 hours per day irrespective of the dry or wet climate. However, in the Anamaduwa-Puttalam area, it was 14 hours during the dry period while it may extend up to 21 hours during the wet period. The average daily per capita domestic water consumption in the Kalpitiya area was $72.4 \mathrm{~L}$ while in the Anamaduwa-Puttalam area, it was $81.5 \mathrm{~L}$. The EC of groundwater in the Anamaduwa-Puttalam area varies from 0.479 to $35.42 \mathrm{dS} / \mathrm{m}$ (average $3.336 \mathrm{dS} / \mathrm{m}$ ) whereas the TDS varies from 319 to $23360 \mathrm{mg} / \mathrm{L}$ (average $2190 \mathrm{mg} / \mathrm{L}$ ). However, in Kalpitiya peninsula EC varies from 0.339 to $5.980 \mathrm{dS} / \mathrm{m}$ (average $1.457 \mathrm{dS} / \mathrm{m}$ ) whereas the TDS varies from 223 to $3847 \mathrm{mg} / \mathrm{L}$ (average $962 \mathrm{mg} / \mathrm{L}$ ). Barring of groundwater flow through faulted basins in Andigama-Anamaduwa area and near the unconformity between Wanni complex and limestone belt are hydro-geologically responsible for the higher EC $(>2.500 \mathrm{dS} / \mathrm{m})$ and TDS $(>2000 \mathrm{mg} / \mathrm{L})$. Seawater intrusions along with sandy aquifers in the Kalpitiya peninsula are responsible for the EC/ TDS variations. Moreover, Kalpitiya indicates better prospects compared to landward areas. The outcome highlighted future water sector challenges in support of achieving the Sustainable Development Goal (SDG) target 6 in the study area.
\end{abstract}

Keywords: SDG 6; saline water intrusion; sedimentary aquifers; water quality, Sri Lanka.

\section{INTRODUCTION}

The influx of more modern water supply mechanisms resulted in decreasing the differences between those having access to clean water in the urban and rural areas. However, eight out of ten people living in rural areas are still without access to safe drinking water and depend on untreated lakes and rivers (WHO, 2018). Therefore, rural drinking water supply remains a priority agenda for many governments. The authorities are focusing on the protection of drinking water, since its impacts on public health, economy, environment, and social development of nations are substantial (UNICEF, 2016). Even water used for domestic (other than drinking), agriculture and food production, etc. also need to be sufficiently safe enough so that subsequent contributions to the society could be environmentally sound and minimally adverse. The economic growth and reduction of poverty can be boosted by improved water supply, proper sanitation, and better water management. As Sustainable Development Goal (SDG) target 6 meant for safe and affordable drinking water, the source must satisfy indicators such as located on-premises, available when needed, and free from fecal and chemical contamination (WHO, 2018).

About $40 \%$ of the world's population lives in coastal areas extended up to $60 \mathrm{~km}$ towards the hinterland (Jayasekera et al., 2011). The accessibility to good quality water in the coastal areas, however, poses a challenge due to population increase, industrialization, agriculture, and tourism. Depletion and pollution of surface water led to excessive use of groundwater, which makes up for a shortfall in many coastal areas, where, groundwater is vulnerable to contamination due to anthropogenic activities (Edirisinghe et al., 2016). The dearth of regulated abstraction and sustainable pumping programs in the coastal aquifers tend to shrink groundwater reserves. The ultimate result would be landward movement of freshwater-sea water interface instigating salinization of the freshwater lens. In semi-arid coastal regions, precipitation is also limited so that freshwater supplies to all sectors become a problem (Jayasekera et al., 2011).

In the dry zone of Sri Lanka, the average annual rainfall $<1750 \mathrm{~mm}$ with monthly rainfall vary in a bimodal distribution indicating temporal variations in the water supply to the population during dry periods (Jayasena et al., 2008). The water competition index for Sri Lanka was about 400 persons for one million cubic meters per year 
in 1980 (Forkasiewicz and Margat, 1980) and expected to increase up to 500 with the population forecast at 23 million by the year 2025 (Molden et al., 2001; Hussain et al., 2002).

The socio-economic state and health conditions of people living in the dry zone mainly depend on the water extracts through an extensive network of tube wells drilled into the coastal sandy, the regolith (average up to $10 \mathrm{~m}$ ), and the fractured rock aquifers (average up to $30 \mathrm{~m}$ and deep lineaments). Groundwater is usually considered to be less abundant in the hard-crystalline terrain due to the extremely low porosity (Bedinger et al., 1986; Jayasena et al., 1986; Wright, 1992). However, a network of subsurface channel system-generated by weathering along with fractures, joints, faults, and shear zones developed endogenetically in the earth's upper crust, supports the occurrence and movement of groundwater (Jayasena, 1995; Jayasuriya and Jayasena, 2019). Groundwater availability along the coastal belt is high and plays a vital role to maintain a sustainable healthy lifestyle. However, obtaining good quality water is still a challenge due to seawater intrusion (Edirisinghe et al., 2016).

\section{Importance of the Study}

Anamaduwa-Puttalam and Kalpitiya areas are densely populated $\left(515 / \mathrm{km}^{2}\right.$, Department of Census and Statistics, 2012) which indicates significant water demand shortly. Anamaduwa-Puttalam area has been rapidly developing with industrial activities while Kalpitiya area has dominant agricultural practices. Therefore, both areas expect a higher usage of groundwater as the surface water was insufficient to cater to the demand. People of both areas tend to extract groundwater on a large scale by constructing dug and tube wells into subsurface unconsolidated sandy and deep sedimentary limestone aquifers. The excessive groundwater usage has caused several detrimental environmental impacts, such as the depletion of groundwater table due to unregulated pumping (Water Resources Board, 2010) and deterioration of water quality due to saltwater intrusion and agrochemical usage (Kuruppuarachchi and Fernando, 1999; National Water Supply and Drainage Board, 2008; Jayasingha et al., 2011; Jayasingha et al., 2013; Jayasingha et al., 2014; Kumarasinghe and Rajapakse, 2013; Jayathunga et al., 2020). To cater solutions to the aforementioned issues, a general understanding of the physical regime and groundwater dynamics are necessary, which would depend on geology, land use, climate, and other environmental factors of the respective areas.

The present study focuses on heterogeneous hydrogeological environments in the northwest of Sri Lanka. It covers coastal sand, fractured Wanni Complex, and the Miocene limestone formations on one hand (Panabokke and Perera, 2005) and major structural geological boundaries and Jurassic sediment bearing faulted basin on the other (Figure 1). Further, the experience-based contributions from the end-user are also vital in terms of understanding the social norms on agricultural and domestic water usage. Therefore, a social survey was designed to acquire further important SDG 6 assessments. Besides, it also focused on identifying the salinity and other environmental problems related to domestic and agricultural water usage as faced by the residents in the Kalpitiya and Anamaduwa-Puttalam area.

\section{MATERIALS AND METHODS}

\section{Study Area}

This study was confined to the northwest Dry Zone of Sri Lanka covering an area encompassing Anamaduwa (longitudes $79.8345^{\circ} \mathrm{E}$ and latitudes $8.0338^{\circ} \mathrm{N}$ ), Puttalam, and Kalpitiya peninsula (longitudes $79.7596^{\circ} \mathrm{E}$ and latitudes $8.2295^{\circ} \mathrm{N}$ ). The average annual temperature of the study area is $28.0^{\circ} \mathrm{C}$. The average annual rainfall with a bimodal distribution due to Inter-Tropical Convergence Zone (ITCZ) varies from 1174 to $1067 \mathrm{~mm}$ (Beck et al., 2018). Kalpitiya Peninsula falls adjacent to the coastal lagoon beyond Puttalam. The lagoon has a depth of about $1.7 \mathrm{~m}$ and a length of about $45 \mathrm{~km}$ to develop well-defined salinity during the tidal range. During the dry season, inner end salinity may reach $50 \%$ (Jayasiri et al., 1998), however, overall salinity varies from 32 to $42 \%$ (Arulananthan et al., 1995). During wet and dry periods, two distinguished temporal water quality variations were identified. These salinity variations can be affected by high evaporation in combination with seasonal monsoonal rainfall.

\section{Geohydrology and Physiography of the Kalpitiya and Anamaduwa-Puttalam regions}

Geologic formations of the coastal belt of Kalpitiya and Puttalam areas are mainly underlain by unconsolidated sand and Miocene sedimentary sequence whereas the inland area in Anamaduwa is underlain by Wanni Complex hard rocks. Brittle block faulting within hard rock formation is partially responsible for changing the spatiotemporal geochemistry of groundwater (Jayasena, 1993). The land use pattern, hard-rock geology, and restricted groundwater flow are the other factors making the variation of groundwater geochemistry (Jayasena, 1993; Jayathunga et al., 2020).

The occurrence and movement of groundwater in the Miocene limestone and other coastal areas are characteristically different from the hard rock terrain (Weerasinghe and Jayasena, 2012; Chandrajith et al., 2016). The limestone formation in the northwest is the dominant source of groundwater storage due to its prominent karstic nature and the presence of enlarged joints and fissures as well as immense solution cavities and subsurface chambers (Cooray, 1984). Therefore, sedimentary limestone and sandstone in the northwest, as they tend to have higher porosity and permeability, expect to contribute higher groundwater potential. Depth-wise variations of groundwater geochemistry were also observed in the Miocene limestone although it was not prominent in hard rock aquifers (Wetselaar et al., 1993).

Kalpitiya peninsula is one of the highly productive unconfined aquifers in Sri Lanka and is characterized by shallow sandy aquifer derived from marine origin during the Quaternary age (Cooray, 1984; Jayathunga et al., 2020). Generally, the area is flat with slightly higher elevations in the central part due to paleo dunes. The western margin is sustained with recent dunes developed by monsoon winds 


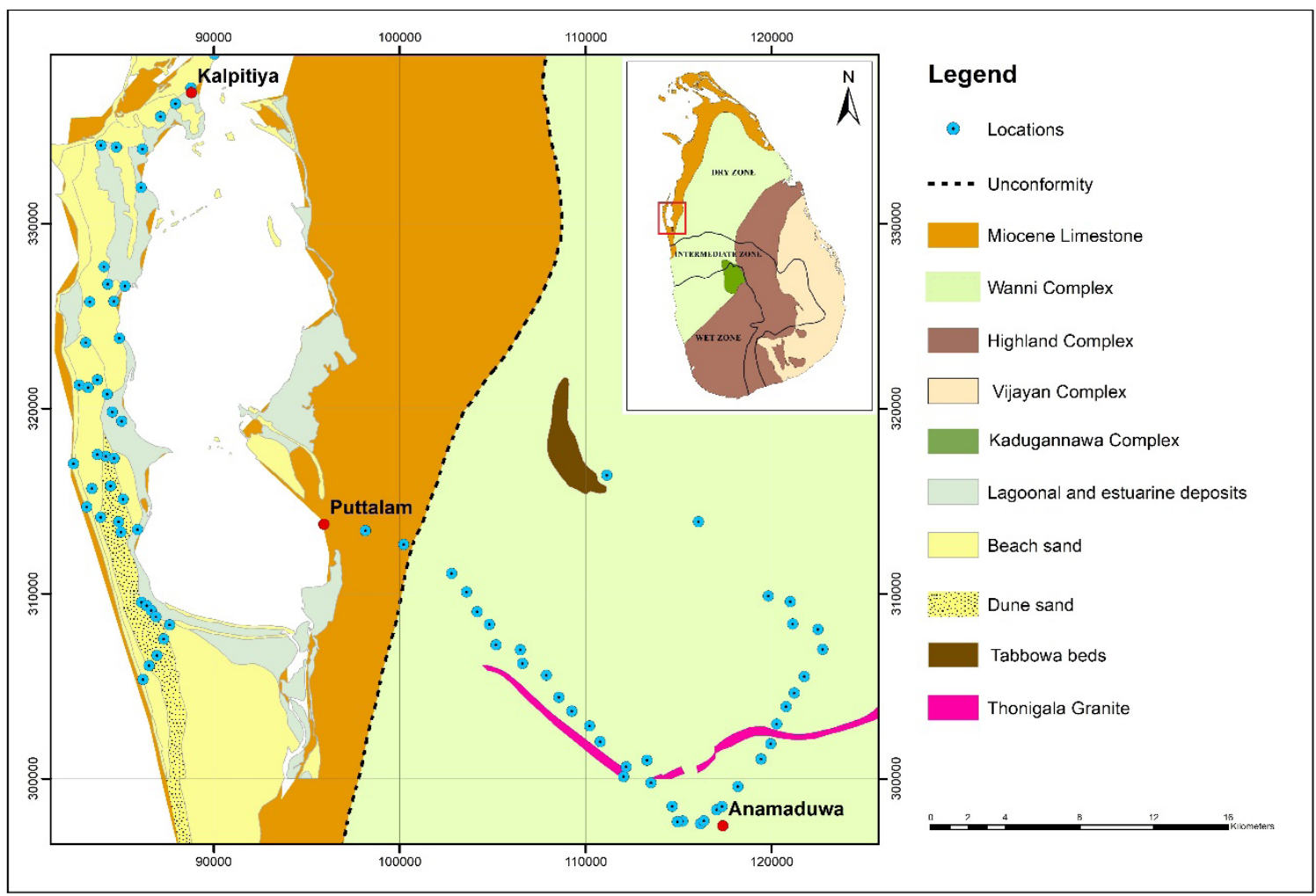

Figure 1: Study area including geological formations and sampling locations. The inset showing the major lithologic units and climatic boundaries from wet, intermediate to dry zones in Sri Lanka (Modified after GSMB Geological Map, 1997).

(Cooray, 1984). This aquifer has thinner freshwater lenses which mainly recharge during the rain in the "Maha" season (starts in September and ends in March during northeast monsoon). The volume of freshwater in such aquifers usually expands during the rainy season and contract during the dry season resulting in fluctuating brackish and saline interface (Panabokka and Perera, 2005).

\section{Water Quality Analysis}

A total of 42 groundwater samples, 18 from the west of the unconformity and 24 from the east, were collected from representative wells in the Kalpitiya area during three field visits to obtain real-time in-situ field measurements of Electrical Conductivity (EC) and Total Dissolved Solids (TDS). Groundwater levels of the respective wells were measured using measuring tapes. Water level fluctuations were assessed using previous knowledge of water level change by the owner. The first batch of fifteen (15) samples was collected in May followed by fifteen (15) samples in August and twelve (12) samples in October of 2018. The sampling program was conducted in a dry period to represent the measurements accurately and uniformly on groundwater quality, since the rainy season may impose significant changes due to infiltration and subsurface flow. All the samples were collected from dug or tube wells used for agricultural and domestic purposes. Most of the dug wells are lined using concrete moldings. The existing water pump and/or bucket was used to collect samples, however, water stored in the constructed cement tanks was avoided. Electrical Conductivity (EC) measurements were taken using a field-portable EC/TDS/Salinity meter (HACH SensION 5) immediately after sampling. Before taking measurements, the conductivity meter was calibrated using $0.084 \mathrm{dS} / \mathrm{m}, 1.413 \mathrm{dS} / \mathrm{m}$, and $12.88 \mathrm{dS} / \mathrm{m}$ standard conductivity solutions. The $\mathrm{pH}$ was measured using the Orion $290+\mathrm{pH}$ meter.

\section{Social Survey}

A questionnaire-based social survey was conducted during May, August, and October 2018 covering Kalpitiya and Anamaduwa-Puttalam areas. The survey was conducted to assess several SDG 6 goals concerning community interests at 42 locations in the Kalpitiya area and 40 locations in the Anamaduwa-Puttalam area. Household owners were interviewed to obtain data on water usage and hydrogeological information. Data on quantity, quality, water levels, fluctuation range during the dry and the rainy periods were collected. Per capita, water consumption for drinking and sanitation purposes were calculated from the respective wells. However, enumerators were faced with difficulties in collecting some crucial inputs during data collection. Since most families were engaged in agricultural and day to day activities, relevant household personnel were not readily available at some locations. Also, the data collection was inadequate in areas where transport issues prevailed especially under forest coverage. Therefore, the questionnaire surveys were not conducted at such places. At certain villages, several interviewees were hesitant to give answers to some of the survey questions. Therefore, the enumerator had to pay special attention to assess the 
domestic water consumption at each location, which was measured based on containers used for drinking, washing, cooking, bathing, and sanitary purposes. Containers were refilled with the standard measure to obtain the respective volumes that the family consumed per day. Usually, the residents in both areas gave a weekly volume to be converted to a daily per capita consumption. A reasonably good data set was collected with satisfactory quality assurance from the short field survey conducted in both areas.

\section{Desk Studies}

Secondary data covering Anamaduwa-Puttalam and Kurunegala regions were collected from the Water Resources Board (WRB) archives. The WRB database was used to collect water quality assessment, water levels and fluctuation range, EC, and TDS, etc., and analyzed for spatiotemporal distributions using ArcGIS. The purpose is to prepare spatial distribution plots of above parameters across the Anamaduwa, Puttalam, and Kalpitiya areas. Subsequently, the outputs were combined with the social survey data of the present study for further interpretation. The data were synthesized to prepare a schematic section with $2 \mathrm{D}$ transects covering different aquifers and structurecontrolled groundwater circulation cycles.

After extracting the data from the questionnaire survey, the matrices were prepared for further analysis. Descriptive statistical analysis and normality tests were performed for cooking, washing, sanitary, bathing, and drinking water usage for both Puttalam and Kalpitiya areas. To compare each category between the two study areas, the nonparametric Mann-Whitney U test was utilized (R Core Team, 2019), keeping the " $\alpha$ " value as 0.05 . Similarly, descriptive statistics and normality tests were also performed for depth to water levels covering wet and dry seasons for both areas.

\section{RESULTS AND DISCUSSION}

\section{Domestic Water Consumption}

In terms of drinking water, the Institute of Medicine (US) recommends total daily water intake to be $3.7 \mathrm{~L}$ for the average adult male and $2.7 \mathrm{~L}$ for the average adult female (Institute of Medicine (US), 2005). The daily per capita drinking water consumption may vary according to climate conditions, free availability, and social norms. The present survey resulted in 2.1 L for the Kalpitiya peninsula and 2.4 $\mathrm{L}$ for the Anamaduwa-Puttalam area. These lower values may reflect the financial burden of the residents in the respective areas since drinking water is usually bought from private suppliers who provide purified water at a cost of around 1-2 Sri Lankan Rupees (LKR) per liter. Since it adds to the living cost of each family, better off residents in the Anamaduwa-Puttalam area have additional incentive to buy drinking water compared with the relatively poor peasant families and residents in the Kalpitiya peninsula. The drinking water consumption in both areas is relatively less than the recommended level by the Institute of Medicine (US). Such inadequate drinking water intake may indirectly refer to the rising cost of the drinking water (free in the past to LKR 1-2 at present) and ultimately affect the overall health of the people living in the two areas.

The daily per capita domestic water consumption in the Anamaduwa-Puttalam area was $81.5 \mathrm{~L}$ and in the Kalpitiya area, it was $72.4 \mathrm{~L}$ (Table 1). Though there is a slight difference, the result may indicate how diverse social backgrounds could influence water consumption. Anamaduwa-Puttalam area is more urbanized than the Kalpitiya area (Department of Census and Statistics, 2012), therefore people in the Anamaduwa-Puttalam area may tend to use more water in their day-to-day activities. The domestic water consumption for cooking, washing, sanitary requirements and drinking has resulted in slightly different percentages. However, significant change is noted in the bathing requirements from both areas (Table 1).

Moreover, the water consumption for sanitary and bathing purposes is relatively low compared with previous studies completed in the intermediate zones within the Deduru Oya basin (Jayasena and Selker, 2007; Jayasena and Dhanapala, 2014). Bathing on average is usually done three times per week in both Anamaduwa-Puttalam and Kalpitiya areas, so daily bathing consumption becomes a low value (52.6 and $59.4 \mathrm{~L} /$ person/day respectively). However, bathing water consumption in the Deduru-Oya basin (Jayasena and Selker, 2007) resulted in 78.5 L/person/ day. Therefore, such low consumption for bathing in the respective study areas may result due to inadequate water availability and poor water quality. For instance, bathing with brackish water causes difficulties in the removal of the soap from the body. Similarly, the hair is also affected so that the people responded with their reluctance to have a regular bath with low-quality water. On the other hand, many households use plastic basins $(15 \mathrm{~L})$ to collect water and repeatedly reuse it during washing clothes and bathing. This practice of repeated reuse of water from wells may facilitate less per capita water consumption (Table 1) when compared with the previous results from the Deduru-Oya basin (per capita consumption of $9.18 \mathrm{~L} /$ day for washing and $78.5 \mathrm{~L} /$ day for bathing). In Kalpitiya area domestic wastewater is mainly poured into the plants, however, due to the porous sandy soil sometimes wastewater directly discharges into the soil as well. In Anamaduwa-Puttalam wastewater dominantly diverts into natural drainage indicating that the Kalpitiya area wastewater discharge is more sustainable than the Anamaduwa-Puttalam area.

The interquartile range (IQR) of daily per capita water consumption for cooking in the Kalpitiya area is slightly higher than that of the Anamaduwa-Puttalam area, indicating some variation in water consumption for cooking among the population in the Kalpitiya area (Figure 2). However, both distributions are positively skewed, but with an outlier in the Anamaduwa-Puttalam area. There is a slight difference when considering the distribution of daily per capita water consumption for washing in both areas (vary between 6 and 8). However, it shows a normal distribution without any outliers in the Anamaduwa-Puttalam area. The IQR distributions for the sanitary water consumption are the same for both areas. However, the range is higher in the Anamaduwa-Puttalam area, indicating an artifact 
Table 1: Average domestic water consumption (L/person/day) and standard deviation (s)

\begin{tabular}{ccc}
\hline Purpose & $\begin{array}{c}\text { Kalpitiya (s) } \\
\mathbf{N = 4 2}\end{array}$ & $\begin{array}{c}\text { Anamaduwa-Puttalam (s) } \\
\mathbf{N = 4 0}\end{array}$ \\
\hline Drinking & $2.1(0.7)$ & $2.4(0.7)$ \\
\hline Cooking & $3.4(0.9)$ & $4.1(0.9)$ \\
\hline Washing & $6.8(1.0)$ & $7.0(1.0)$ \\
\hline Sanitary & $7.5(1.3)$ & $8.4(1.2)$ \\
\hline Bathing & $52.6(5.8)$ & $59.6(4.7)$ \\
\hline Total Consumption & $\mathbf{7 2 . 4}$ & $\mathbf{8 1 . 5}$ \\
\hline
\end{tabular}

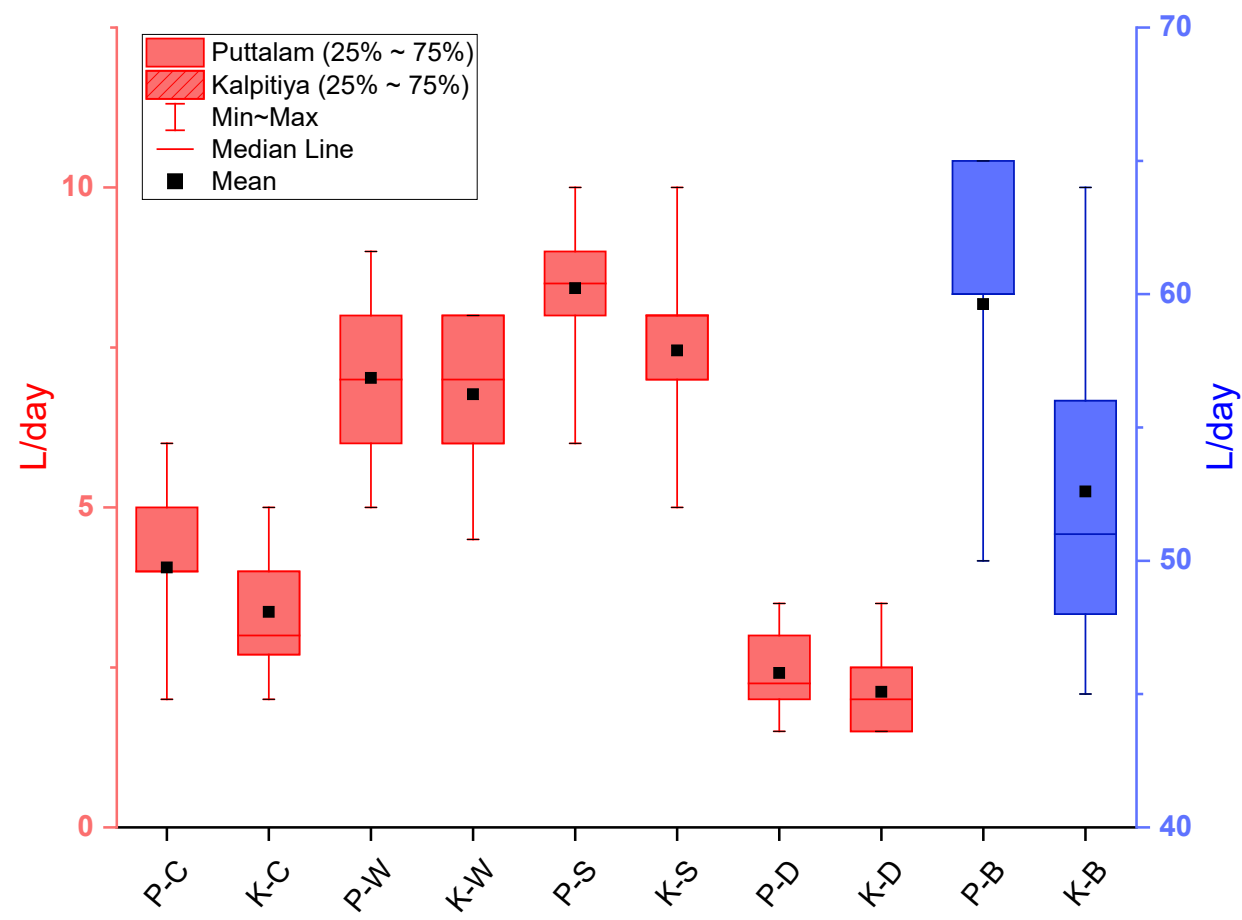

Figure 2: Box and Whisker plots of per capita domestic water consumption for Puttalam (P) and Kalpitiya (K) areas. C-Cooking; W-Washing; S-Sanitary; D-Drinking; B-Bathing.

of urbanization (Figure 2). The outliers identified in both areas may reflect the difficulty in getting an approximate value for the sanitary consumption. Moreover, the IQR values for bathing have the highest among the distributions of domestic water consumption. The respective IQR for bathing varies from 8.5 to $5 \mathrm{~L} /$ person/day in Kalpitiya and Anamaduwa-Puttalam areas, respectively.

Figure 3 display the grouping of data sets of individual water usage categories for Anamaduwa-Puttalam and Kalpitiya areas. Except for sanitary water usage in Kalpitiya, the other categories were skewed, however, the normality tests indicated that all categories were nonnormal. When comparing each category between the two study areas using the nonparametric Mann-Whitney U test (R Core Team, 2019), keeping the " $\alpha$ " value as 0.05 , the washing water usage between the two study areas came up with a p-value of $0.38(>0.05)$. However, all the other categories are significantly different from each other (Table 2). The statistical distributions of drinking water consumptions have lower values than other water consumption values, however, the distribution in the Anamaduwa-Puttalam area is positively skewed (Figures 3a and $b$ ). The statistical distribution of the water consumption for bathing is positively skewed in the Kalpitiya area while it is negatively skewed in the Anamaduwa-Puttalam area (Figure $3 \mathrm{c}$ and $\mathrm{d}$ ). This may be due to the water quality as it is better in the Kalpitiya area than the AnamaduwaPuttalam area. In general, overall mean consumption values of the Anamaduwa-Puttalam area are higher than that in the Kalpitiya area. This may also reflect the economic conditions in two areas as discussed early.

\section{Water Level Fluctuations}

The water level fluctuations during dry and wet periods were extracted from the dug well owners. Since elderly people have reasonably good knowledge about previous water level fluctuations, the focus of getting data skewed on to them. Water level fluctuations (Table 3) indicate that the Anamaduwa-Puttalam area has a relatively higher water level change than the Kalpitiya area. 

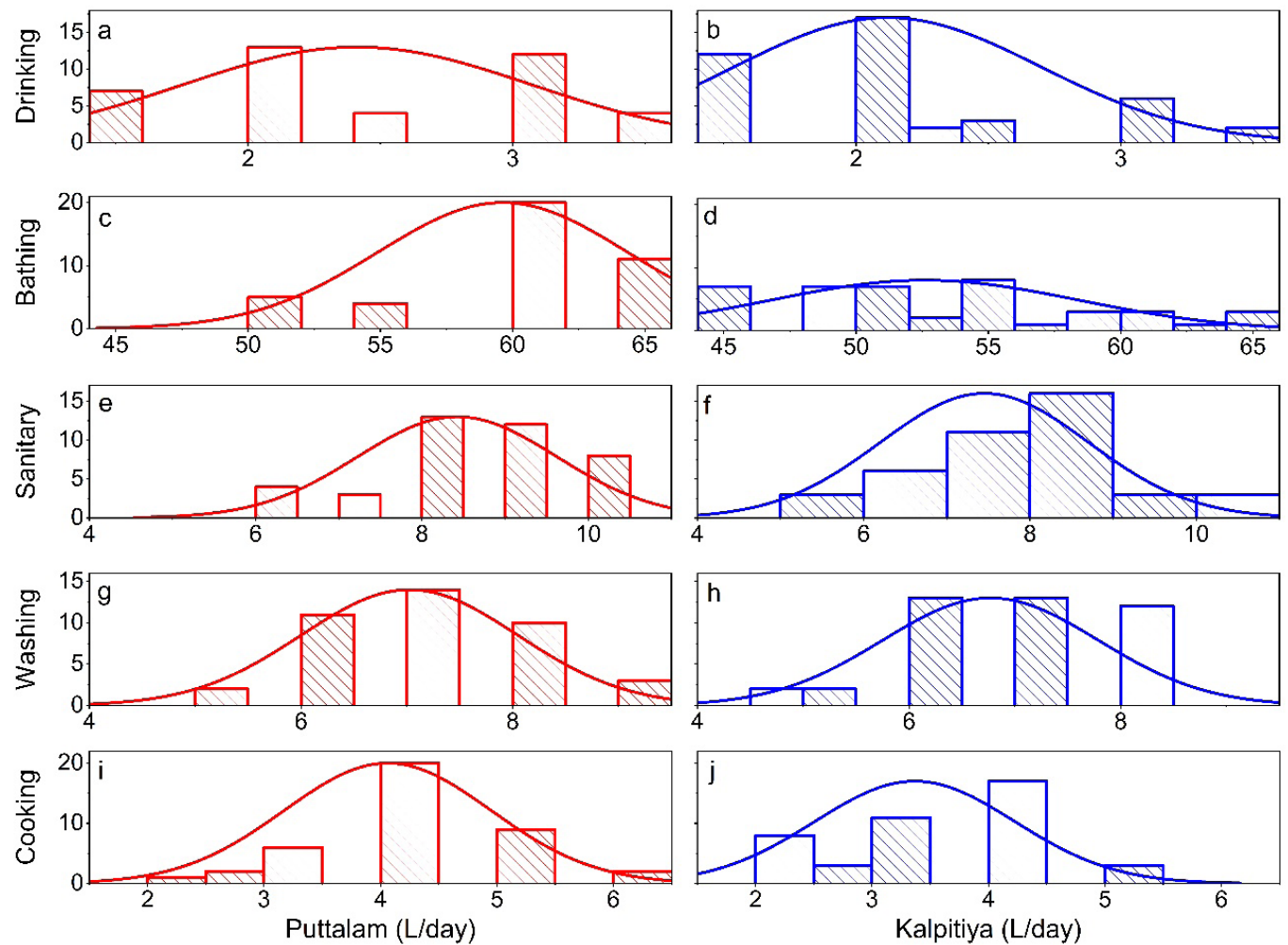

Figure 3: Histograms showing the respective counts for drinking, bathing, sanitary, washing, and cooking water usages (L/day) for Puttalam and Kalpitiya areas.

Table 2: Mann-Whitney U test results for each category

\begin{tabular}{ccc}
\hline Category & $\boldsymbol{p}$-value & Significance \\
\hline Cooking & $1.05 \times 10^{-03}$ & $\mathrm{SD}$ \\
\hline Washing & $3.82 \times 10^{-01}$ & $\mathrm{ND}$ \\
\hline Sanitary & $4.80 \times 10^{-04}$ & $\mathrm{SD}$ \\
\hline Bathing & $2.50 \times 10^{-07}$ & $\mathrm{SD}$ \\
Drinking & $4.72 \times 10^{-02}$ & $\mathrm{SD}$ \\
\hline
\end{tabular}

SD - Significantly Different, ND - Not Significantly Different

Table 3: Average depth to the water table ( $\mathrm{m})$ and standard deviation $(\mathrm{s})$ during the dry and the rainy seasons $(\mathrm{n}=82)$

\begin{tabular}{ccc}
\hline Season & Kalpitiya (s) & Anamaduwa-Puttalam (s) \\
\hline Dry & $6.39(6.15)$ & $8.52(5.16)$ \\
\hline Rainy & $2.95(1.22)$ & $2.25(2.18)$ \\
\hline
\end{tabular}

However, the average water level fluctuation in the Anamaduwa-Puttalam area was $6.27 \mathrm{~m}$ while in Kalpitiya it was $3.44 \mathrm{~m}$. Therefore, during the dry period, available water quantity in the Anamaduwa-Puttalam area becomes a problem than the Kalpitiya area. Such differences may reflect the aquifer properties in respective areas, where Kalpitiya has sandy sediment sequences while Anamaduwa-Puttalam has regolith developed on crystalline rocks. Kalpitiya peninsula is one with high productive unconfined aquifers in Sri Lanka, and it is characterized by shallow groundwater-bearing sandy aquifer derived from marine origin during the Quaternary age (Cooray, 1984). However, the Anamaduwa-Puttalam area, on the other hand, is a crystalline terrain with shallow regolith which yields less groundwater when compared with the sedimentary terrain. This is due to the less permeability associated with the regolith and the crystalline rocks. Yet local pockets of deeply weathered and faulted rock mass are rarely found which yield a significant amount of water (Jayasena et al., 1986). Therefore, rainfall recharge to replenish groundwater is higher in Kalpitiya than in the Anamaduwa-Puttalam area. It is recorded that the water level fluctuation in Kalpitiya was low may be indicative of quick recharge both from rainfall and irrigation return flow while in the Anamaduwa-Puttalam area it is high may be indicative of recharge through regolith only during the rainy season. 
The descriptive statistics and the normality tests for the water levels in the wet and the dry periods suggest that only the water level in the rainy season of the Puttalam area is normally distributed. Figure 4 illustrates the histograms, skewness and, kurtosis based on the respective counts of depth to water levels recorded in both areas. As the depth to water level counts are non-normal, it was decided to continue analysis with non-parametric tests. To identify whether the water levels in the two study areas behave differently from each other, the Mann-Whitney U test was employed. Results indicate that both parameters considered for the test are significantly different (Table 4).

\section{Public Water Supply Schemes}

Water supply is predominantly from the "Praja Muula" (managed by community-based organizations) storage tanks or large diameter wells constructed in the area. The dimensions of one of those representative wells are $6.10 \mathrm{~m}$ in diameter, depth $10 \mathrm{ft}$ (3.3 m), and use two, 2.5-inch (635 $\mathrm{mm}$ ) pumps to deliver water. The pipes were laid to connect households using public funds contributed by residents in the area. However, the water supply from the piped lines is insufficient to cater to the demand. Continuous water supply is a major problem in the Anamaduwa-Puttalam area and during the dry period, it is only about $14 \mathrm{~h}$ per day. Even in the rainy period, $24 \mathrm{~h}$ supply is not guaranteed. Therefore, these households usually store water in plastic-shells (500 L-1000 L). Even if the source is located within the premises the supply may not be sufficient or readily available to cater to the domestic water demand. The drinking water supply in Kalpitiya was $24 \mathrm{~h}$ per day irrespective of the dry or wet climate. Moreover, both areas are facing environmental problems that resulted in deteriorating drinking water sources. These reasons may become barriers to achieve Target 6 of the Sustainable Development Goals in Kalpitiya and Anamaduwa-Puttalam areas as it deals with clean water and sanitation (WHO, 2018).

\section{Agricultural Water Consumption}

Agriculture is the most dominant livelihood in the Kalpitiya area. The farmers cultivate coconuts and other cash crops such as mangoes, tobacco, chilies, beetroot, onions, brinjals, green beans, okra, and cabbages. Intense watering has been practiced in Kalpitiya to maintain moisture (field capacity)
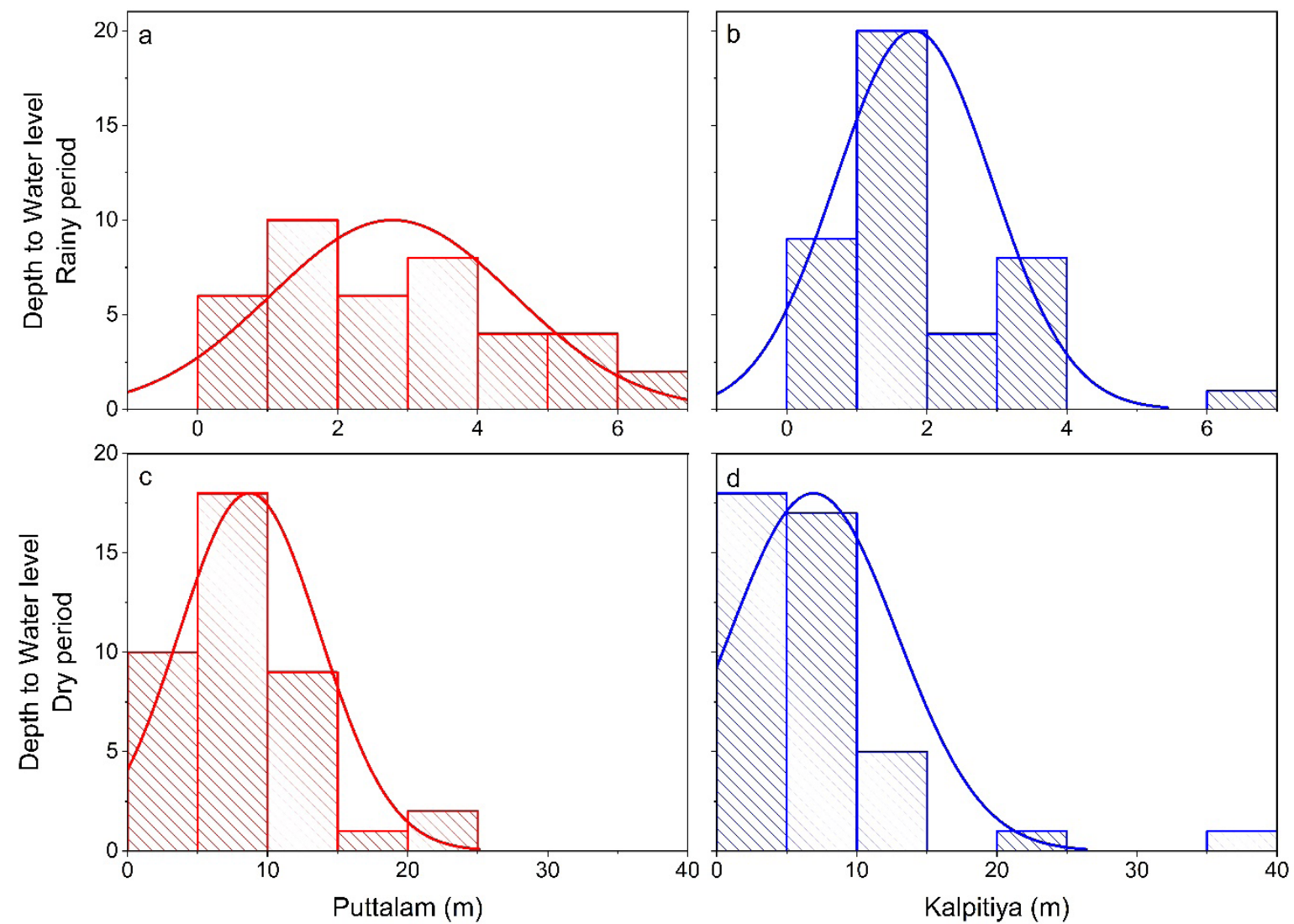

Figure 4: Histograms showing the respective depth to water level counts recorded at Puttalam and Kalpitiya wells during the dry and the rainy periods.

Table 4: Mann-Whitney U test results for water levels in dry and rainy periods between Puttalam and Kalpitiya

\begin{tabular}{ccc}
\hline Category & p-value & Significance \\
\hline The water level in a dry period & $2.22 \times 10^{-02}$ & $\mathrm{SD}$ \\
The water level in a rainy period & $1.10 \times 10^{-02}$ & $\mathrm{SD}$ \\
\hline SD - Significantly Different, ND - Not significantly Different
\end{tabular}


in the dry sandy soil. However, the cultivation of seasonal crops was very much less in the Anamaduwa-Puttalam area mainly due to inadequate water supply. Sprinklers were used for irrigation in the agricultural fields, besides rubber drag hoses were also used for flood irrigation. To assess the agricultural water consumption at different stages, the following point values were either recorded or extracted from the Kalpitiya area. The flood irrigation for the initial preparation period using drag hoses is estimated at 435 $\mathrm{m}^{3} /$ day/ha based on a total of $17 \mathrm{~h}$ of pumping using three different wells. Another calculation done by Melvani et al., (2006) indicates that the daily water requirement for drag hose irrigation is $185 \mathrm{~m}^{3} /$ ha based on two 25 minute sessions per day, however, for sprinkler irrigation, it was approximately $177 \mathrm{~m}^{3} /$ ha for 25 minutes. Such high agricultural water consumption was not a problem in the Kalpitiya area due to high infiltration rates (vary from 25 to $200 \mathrm{~mm}$ per hour) and a quick recharge through the sandy aquifer. Therefore, farmers in the Kalpitiya area freely add excessive amounts of water to irrigate their farmlands. However, such unsustainable irrigation practices may result in detrimental effects on water quality since extensive water pumping could facilitate saltwater intrusion (Vacher, 1988).

\section{Brackish Conditions}

People's perspectives on the brackishness of household well water were recorded on a prescribed scale. The interviewee needs to consider previous knowledge to answer the questions. Also, for a better understanding of the brackish condition and to compare the results, a small amount of well water was tasted by the enumerator. Brackishness was categorized into five groups as very low, low, medium, high, and very high depending on the taste, difficulties in washing and bathing purposes. It was noted that well water has a more brackish taste in the Anamaduwa-Puttalam area than the Kalpitiya area. Similarly washing clothes and removing soap are also relatively tougher in the Anamaduwa-Puttalam area than in the Kalpitiya area. Just as when bathing, many interviewees described that they experienced soap not being properly dissolved in water and mostly remained on the skin.

The results were used to construct the kriged distribution covering Anamaduwa-Puttalam and Kalpitiya areas (Figure 5). However, interpretations were undetermined at places when inadequate sampling points were encountered. The brackishness may also be a resultant due to the overpumping of coastal aquifers. The overpumping facilitates saltwater intrusion to the water supply wells. Soil salinity due to excess evaporation and enriching chemical constituents under prevailing dry climate in these areas may also induce brackish conditions. However, during rainy periods, the shallow sandy aquifer in Kalpitiya can be easily recharged than the Anamaduwa-Puttalam area. The high recharging nature in the Kalpitiya sandy aquifer may alter the water quality causing desalinization in the subsurface regime. However, in Anamaduwa-Puttalam area where less permeable regolith bearing crystalline terrain is present, recharging to the phreatic aquifer is relatively less than the Kalpitiya area. Such differences may impose relatively less brackish conditions in the north-west than the south-east of the unconformity (Figure 5). These variations may be caused by the subsurface hydrogeological conditions in the respective areas.

Saltwater intrusion is a major concern in coastal regions (Chandrajith et al., 2014; Gopalakrishnan et al., 2020). Therefore, farmers and water managers should be more vigilant when establishing the pumping rates. Continuous monitoring of groundwater table and regular salinity assessment program needs to be implemented before the problem gets adverse. Considering the severity of the salinity issue, mitigation measures on a case by case can be enforced to prevent saltwater intrusion. For instance, a reduction in the pumping rates of existing wells and/or changing the pumping frequency or well location could be implemented. However, more modern expensive pursuits such as the construction of impermeable subsurface barriers parallel to the coast and artificially constructed freshwater ridges near the sea can also be considered as viable mechanisms (Raicy et al., 2012).

Manage Aquifer Recharge (MAR) is the most environment-friendly and cost-effective method (Kumar et al., 2007), which covers the process of adding water into the aquifer in a controlled manner for withdrawal in future. Also, it is used as a barrier to prevent seawater or another contaminant from entering the subsurface regime. The study in the agricultural areas of Kalpitiya revealed that the MAR could be a viable alternative solution to overcome water issues.

\section{Groundwater Levels}

Groundwater levels are contoured (Figure 6) to understand the variations in the potentiometric surface. The potentiometric surface of the study area generally follows the surface morphology. The distribution revealed that the water levels are changing from 0 to $8 \mathrm{~m}$ except for a few negative values and some deep positive values (up to 20 $\mathrm{m})$. The negative values may represent artesian conditions. The deep positive values may reflect extensive pumping in the vicinity, which may be considered for demarcating potential recharging areas in the future remedial program.

The data are not sufficient yet to extract a meaningful interpretation, however, narrowing of contour intervals contemporary to the boundary between the crystalline basement and limestone terrains could indicate possible steep groundwater gradients. The limestone unconformably resting on the basement and dipping towards the northwest may hinder free flow. On the other hand, Jurassic sediment bearing faulted basins (Tantrigoda and Geekiyanage, 1991), in and around Andigama and Anamaduwa in northwest Sri Lanka may alter the groundwater movement. The faults and shear zones may affect groundwater flow in the subsurface. These structural elements can act as barriers or establish conduits through "fault gouge" for fluid migration (Jayasena, 1993, 1995; Caine et al., 1996; Bense et al., 2013). When subsurface flows meet up at a network of clay-filled structural discontinuities, it could result in localized groundwater pockets with restricted movements.

There may be diversified groundwater flow systems that exist at different depths as described by Toth (1963). 


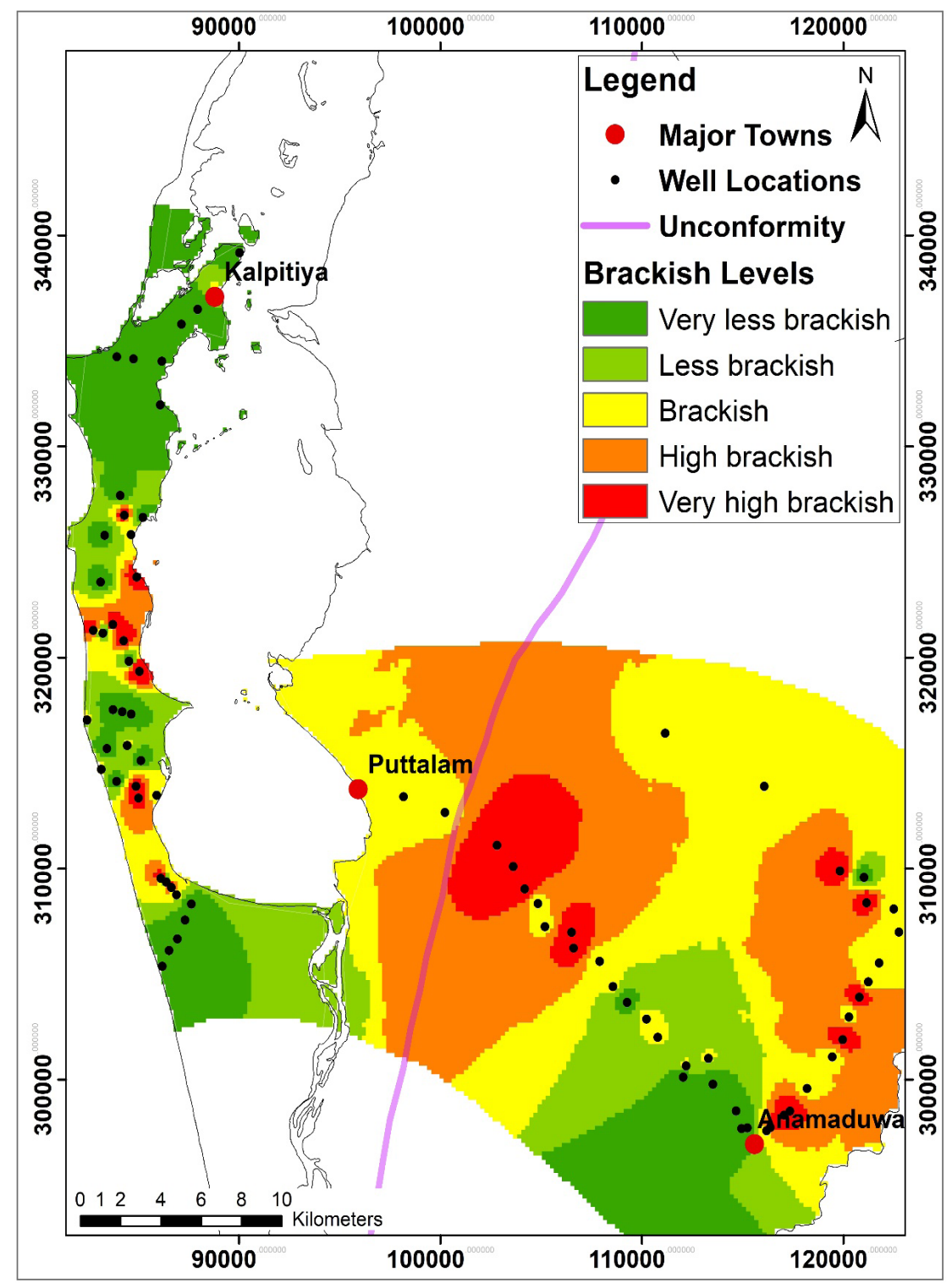

Figure 5: Kriged distribution of brackish condition in the study area.

The functions of such systems may be controlled by the variance of local structures and relief in the respective study areas (Jayasena, 1993, 1995). From the observations, regional groundwater flow towards the west is clear because of recharging water in the crystalline terrain and subsequent discharge through the limestone. The progressive EC and TDS variations are also supporting for such observations. Apart from the regional flow system, the presence of local and intermediate flow systems may also be manifested by the concentrations of groundwater contours at certain locations. These subsurface flow cycles may be inherited due to the presence of endogenetic elements such as faults and shear zones. Therefore, the changing hydrogeochemistry as reflected by the EC variations could be the result of obliterated water circulation.

Shallow groundwater levels can be observed in the areas adjacent to the unconformity between limestone and crystalline terrain. Such accumulation of local groundwater is due to the restricted passage of flow from the crystalline basements towards the limestone terrain. However, very shallow groundwater levels are present due to the reduction of ground elevation towards the cost and rainfed water accumulation in the sandy aquifer. At points, the artesian condition may prevail especially during the heavy rainy seasons as postulated and confirmed by the social survey. Moreover, these groundwater levels could also be elevated by recharged water wandering along with the regional groundwater flow.

On the contrary, higher pumping rates from water supply wells located close to Anamaduwa-Puttalam Towns may register deep groundwater levels. Some of these areas with deeper groundwater were recognized to have higher brackish conditions as well (Figure 5). Thus, it is demonstrated that extensive pumping facilitates the saltwater intrusion and converts the fresh groundwater into a brackish and unpotable reserve.

\section{Water Quality}




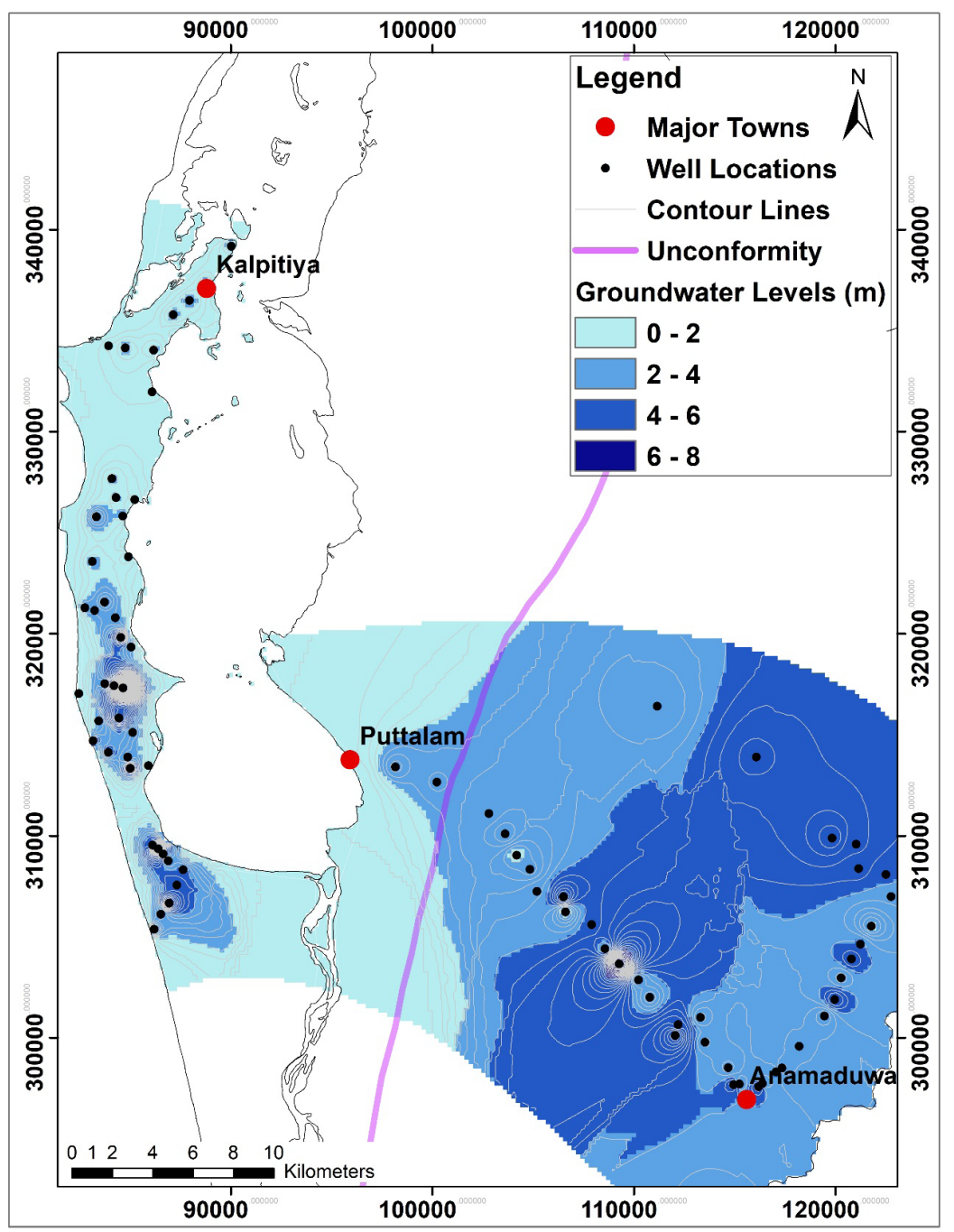

Figure 6: Kriged distribution of depth to groundwater level variations in the study area.

The groundwater with permissible EC below $2.500 \mathrm{dS} / \mathrm{m}$ (WHO, 2018) is observed on either side of the unconformity, which may have shared the regional groundwater flow contributed by recharged water coming from the elevated crystalline terrain. The chemical constituents dissolved in the circulated groundwater are the sources for EC and TDS. The amounts of chemical constituents can be changed by the flow system, controlled by the endogenetic activities in the subsurface, and improved by the saltwater encroachment. The EC of groundwater close to the coastal and lacustrine areas show very high values over $3.500 \mathrm{dS} / \mathrm{m}$. This area is used for commercial solar salterns, which could contaminate the groundwater by mixing with seawater. The high EC for groundwater on the western side of the unconformity could be due to salterns. The values of about $2.000 \mathrm{dS} / \mathrm{m}$ were observed on either side of the elevated groundwater mound (Figure 7). An intermediate groundwater flow has resulted in recharging water passing from the crystalline terrain that could possess similar high EC on the eastern side of the unconformity (Figure 7). Groundwater with higher EC and TDS could also result due to deep circulation cycles associated with the regional and intermediate flow which tend to dissolve constituents from the host rock during long residence times. The regions assigned with higher EC and TDS covering both crystalline and sedimentary limestone terrains could be due to discharging groundwater with concentrated salt accumulation. Moreover, pockets of groundwater with higher TDS and EC in the coastal areas (Kalpitiya peninsula) may be a result of saltwater intrusion aggravated by the extensive pumping.

\section{Groundwater Flow Across Structural Boundaries}

The structural deformities do confirm significant impacts on the groundwater flow and hydrochemistry. As discussed above, patterns of groundwater flow can be ascertained by the variations of the geochemistry of well water (Figure 8). Both EC and TDS distributions display similar signs and behaviors around the structural deformities in the respective study areas. When considering the vicinity of the unconformity between limestone and crystalline rocks, the EC varies with values between $2.500-3.500 \mathrm{dS} / \mathrm{m}$ and TDS varies with values between $1500-2500 \mathrm{mg} / \mathrm{L}$. These values are relatively higher than the surrounding locations, which may indicate influences on groundwater flow by the faulting where the water being trapped and the fault acting as a barrier. As a result, circulated water gradually concentrated with higher ion contents and dissolved solids causing high EC and TDS. Significant higher EC and TDS hotspots were also observed in the Anamaduwa area. With these inputs, a 2D schematic flow model was developed for 


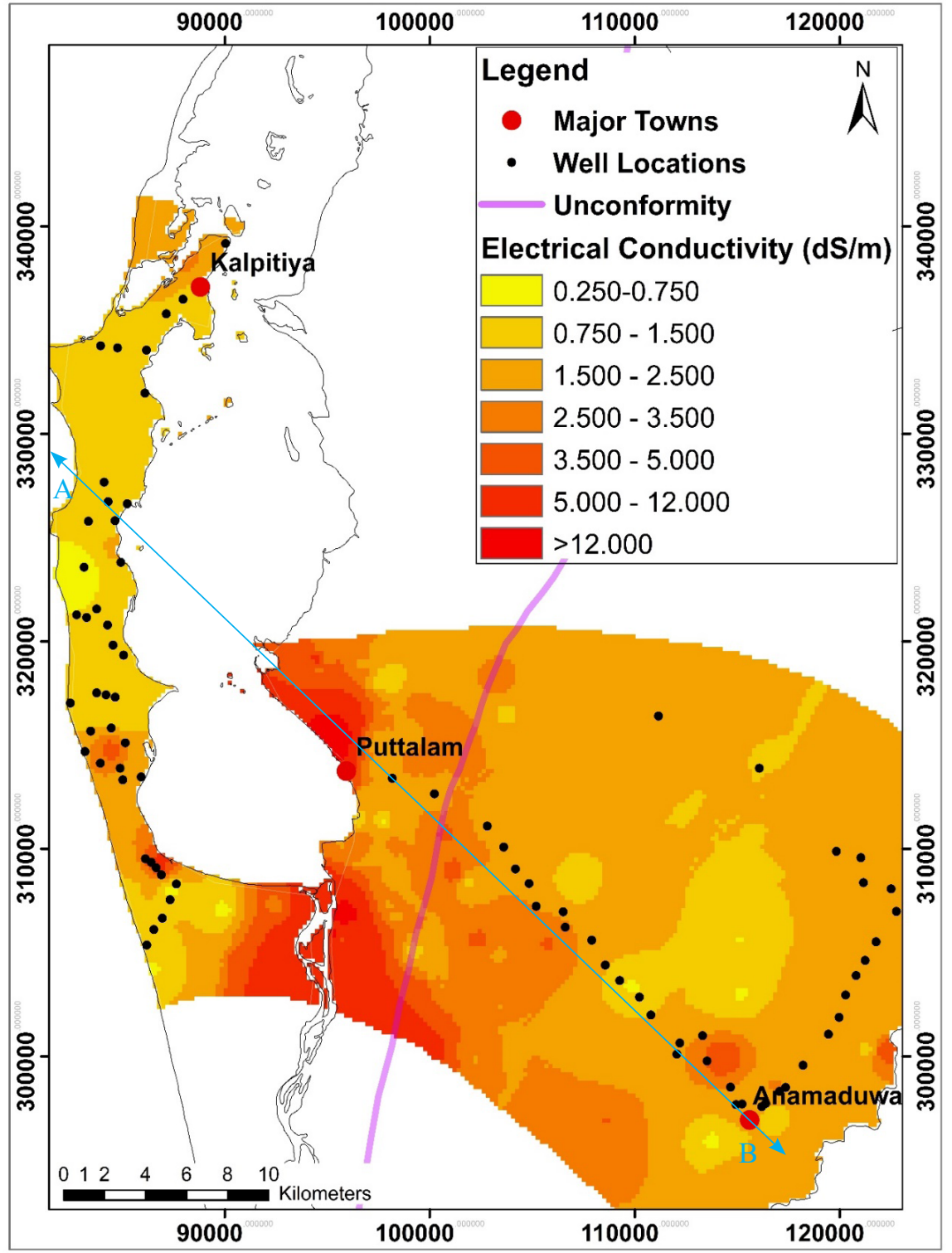

Figure 7: Spatial distribution of electrical conductivity in the study area. The cross-section of AB is schematically represented in Figure 8.

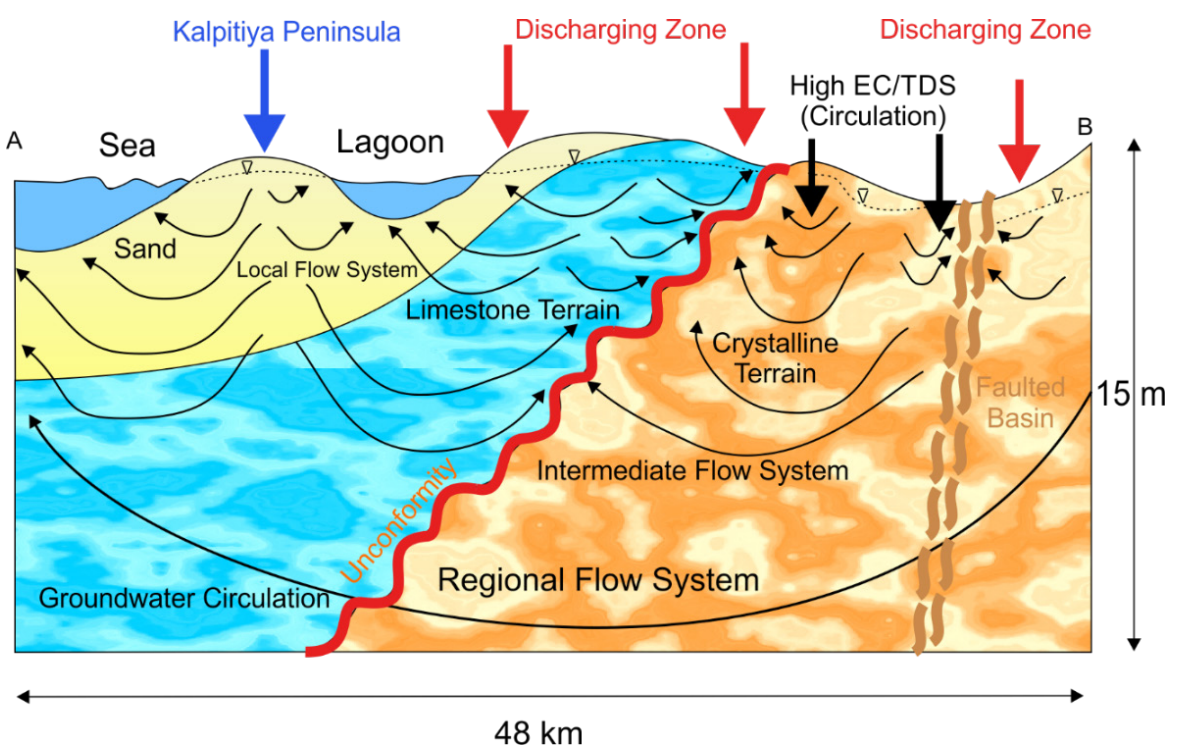

Figure 8: Schematic section of the study area demarcating different flow regimes. 
the study area using possible groundwater flow systems. This includes water circulation restrictions due to structural deformities such as faults, shear zones, and unconformity boundaries (Figure 8).

\section{CONCLUSIONS}

The water quality in the sequence of aquifers covering the coastal sand, limestone, and regolith bearing crystalline basement within the northwestern rolling coastal plains in Sri Lanka falls into relatively poor conditions. The poor water quality may reflect the influence of agriculture, the influx of salinity from the lacustrine environment, and unsustainable pumping for irrigation in the area.

The increase in ion concentrations due to restricted local groundwater circulation associated with faulting may not be controled. However, coastal sandy aquifers should be properly maintained to avoid saltwater intrusion by imposing controlled pumping and effective administrative measures. It is possible to employ convenient mitigation measures such as Managed Aquifer Recharge (MAR) practiced effectively in India to prevent saltwater intrusions.

Groundwater level fluctuations among the study aquifers are significantly different from each other. The complex unconfined and confined aquifer systems present in the study area are mainly recharged from the irrigation return flow and rainfall. With the behavior of chemical signatures such as EC and TDS, it is concluded that the recharge from the crystalline terrain supports the regional flow of groundwater. Moreover, structural elements such as unconformity between limestone and regolith bearing crystalline basement as well as the faulting along with the Jurassic deposits affect the flow regime by restraining local groundwater circulation.

Future groundwater development should concern with achieving SDG 6 though it is not easy due to water supply constraints and water quality problems in the area. Therefore, a policy on sustainability should be devised and maintained by the respective authorities. The efficiency of such a mechanism could be effectively achieved by imposing safe yields to be pumped out from the available groundwater reserves in the area.

\section{ACKNOWLEDGMENTS}

We owe our heartfelt gratitude to several colleagues who attributed to the success of this research. In this respect, we would like to thank Prof. R. Chandrajith, Department of Geology, University of Peradeniya, and all the staff members for their kind support. We are also grateful to the staff members of the Water Resource Board (WRB), Head Office, Colombo, and Provincial Office, Puttalam for the great co-operation provided during the fieldwork, data collection, and analysis. Especially our thanks go to Messrs G.R.R. Karunaratne, General Manager, and K.M.S.M. Kumarasinghe, Area Manager, Regional Office Puttalam for their supports. We also thank the anonymous reviewers for providing extensive inputs that significantly improve the final manuscript. A special thanks goes to Nuthara Hettiarachchi for editorial assistance. Finally, colleagues at the GSMB are also acknowledged for their support.

\section{DECLARATION OF CONFLICT OF INTEREST}

The authors declare no competing interests

\section{REFERENCES}

Arulananthan, K., Rydberg, L., Cederlöf, U. and Wiyeratne, E.M. (1995). Water exchange in a hypersaline tropical estuary, the Puttalam Lagoon, Sri Lanka. Ambio 25(78): 438-443.

Beck, H.E., Zimmermann, N. E., McVicar, T. R., Vergopolan, N., Berg, A., and Wood, E. F. (2018). Present and future Köppen-Geiger climate classification maps at $1-\mathrm{km}$ resolution. Scientific data, 5: 180214-180226.

Bedinger, M.S., Langer, W.H. and Reed, J.E. (1986). Synthesis of hydraulic properties of rocks with reference to the basin and range province, southwestern United States. US Geological Survey Water Supply Paper 2310: 35-43.

Bense, V.F., Gleeson, T., Loveless, S.E., Bour, O. and Scibek, J. (2013). Fault zone hydrogeology. EarthScience Reviews 127: 171-192.

Caine, J.S., Evans, J.P. and Forster, C.B. (1996). Fault zone architecture and permeability structure. Geology 24(11); 1025-1028.

Chandrajith, R., Chaturangani, D., Abeykoon, S., Barth, J.A., van Geldern, R., Edirisinghe, E.A.N. V. and Dissanayake, C.B. (2014). Quantification of groundwater-seawater interaction in a coastal sandy aquifer system: a study from Panama, Sri Lanka. Environmental earth sciences 72(3): 867-877.

Chandrajith, R., Diyabalanage, S., Premathilake, M., von Geldern R., Barth J.A.C. (2016). Controls of evaporative irrigation return flows in comparison to seawater intrusion in coastal karstic aquifers in northern Sri Lanka: evidence from solutes and stable isotopes. Science of the Total Environment 548: 421-428.

Cooray, P.G. (1984). Geology, with special reference to the Precambrian. In: Ecology and Biogeography in Sri Lanka, Springer, Dordrecht, 1-34 Pp.

Department of Census and Statistics. (2012). Retrieved from http://www.statistics.gov.lk/PopHouSat/CPH2011/ Pages/Activities/Reports/FinalReport/ FinalReport.pdf (accessed on 17.12.2018).

Edirisinghe, E.A.N.V., Karunarathne, G.R.R., Samarakoon, A.S.M.N.B., Pitawala, H.M.T.G.A., Dharmagunawardhane H.A. and Tilakarathna I.A.N.D. P. (2016). Assessing causes of quality deterioration of groundwater in Puttalam, Sri Lanka, using isotope and hydrochemical tools. Isotopes in Environmental and Health Studies 52(4-5): 513-528.

Forkasiewicz, J. and Margat, J. (1980). Tableav mondial de données nationals déconomie de l'eav, Bureau de Recherches Géologiques et Mineiéres. Département Hydrogéologie 79 SGN 784 HYD, Orleans, France.

Geological Survey and Mines Bureau. (1997). Geological Map of Sri Lanka. Published by the GSMB, Colombo, Sri Lanka.

Gopalakrishnan, T., Kumar, L. and Mikunthan, T. (2020). Assessment of Spatial and Temporal Trend of 
Groundwater Salinity in Jaffna Peninsula and Its Link to Paddy Land Abandonment. Sustainability 12(9) 3681.

Hussain, I., Thrikawala, S. and Barker, R. (2002). Economic analysis of residential, commercial, and industrial uses of water in Sri Lanka. Water International 27(2): 183193.

Institute of Medicine (US). Panel on Dietary Reference Intakes for Electrolytes, and Water. (2005). DRI, dietary reference intakes for water, potassium, sodium, chloride, and sulfate. National Academy Press.

Jayasekera, D.L., Kaluarachchi, J.J. and Villholth, K.G. (2011). Groundwater stress and vulnerability in rural coastal aquifers under competing demands: a case study from Sri Lanka. Environmental monitoring and assessment 176(1-4): 13-30.

Jayasena, H.A.H. (1993). Geological and structural significance in variation of groundwater quality in hard crystalline rocks of Sri Lanka. In: Sheila and David Banks (Eds.), Hydrogeology of Fractured rocks, Memoirs of XXIVth IAH Congress, Oslo, Norway Pp. 450-471.

Jayasena, H.A.H. (1995). An analysis of fluid flow through fractured rocks. In: K. Dahanayake (Editor), Handbook on Geology and Mineral Resources of Sri Lanka, Second South Asia Geological Congress Souvenir Publication, Colombo, Sri Lanka Pp.87-90.

Jayasena, H.A.H., Chandrajith, R. and Dissanayake, C.B. (2008). Hydrogeochemistry of the groundwater flow system in a crystalline terrain: a study from the Kurunegala district, Sri Lanka. Environmental Geology 55(4): 723-730.

Jayasena, H.A.H. and Dhanapala, T.R.W.S. (2014). Analysis of Domestic Waste Water Usage in a Tropical Mountainous Basin in Sri Lanka. Proceedings of the World Mountain Forum. Moving mountains towards global sustainability, Cusco, Peru, Pp. 23-24.

Jayasena, H.A.H. and Selker, John S. (2007) Rural sector expectations on future water projects a case study from four villages in the Deduru Oya basin in Sri Lanka. Proceedings of the $3^{\text {rd }}$ International Congress on Climate and Water, Helsinki, Finland, Pp.214-220.

Jayasena, H.A.H., Singh, B.K. and Dissanayake, C.B. (1986). Groundwater occurrences in the hard rock terrains of Sri Lanka: a case study. AQUA 4: 214-219.

Jayasingha, P., Pitawala, A. and Dharmagunawardhane, H.A. (2011). Vulnerability of coastal aquifers due to nutrient pollution from agriculture: Kalpitiya, Sri Lanka. Water, Air, and Soil Pollution 219(1-4): 563577.

Jayasingha P., Pitawala A. and Dharmagunawardhana, H.A. (2013). Fate of urea fertilizers in sandy aquifers: laboratory and field case study from Kalpitiya, Sri Lanka. Journal of National Science Found Sri Lanka 41: 121-129.

Jayasingha, P., Pitawala, A. and Dharmagunawardhane, $\mathrm{H}$. A. (2014). Evolution of coastal sandy aquifer system in Kalpitiya peninsula, Sri Lanka: sedimentological and geochemical approach. Environmental earth sciences 71(11): 4925-4937.

Jayasiri, H.B., Rajapaksha, J.K., Rydberg, L. and Cederloef,
U. (1998). The Mundel Lake estuarine system, Sri Lanka; possible measures to avoid extreme salinity and sea level variations. Ambio 27(8): 745-751.

Jayasuriya, C. and Jayasena, H.A.H. (2019). Refined GIS Mapping to Reinvestigate Groundwater Mining Potential Surrounding the Manmade Reservoirs and Tributaries in the Deduru Oya Basin, Sri Lanka. International Journal of Economic and Environmental Geology 10(4): 7-13.

Jayathunga, K., Diyabalanage, S., Frank, A.H., Chandrajith, R. and. Barth, J.A.C. (2020). Influences of seawater intrusion and anthropogenic activities on shallow coastal aquifers in Sri Lanka: evidence from hydrogeochemical and stable isotope data. Environmental Science Pollution Research 27: 23002-23014.

Kumar, S.K., Babu, S.H., Rao, P.E., Selvakumar, S., Thivya, C., Muralidharan, S. and Jeyabal, G. (2017). Evaluation of water quality and hydrogeochemistry of surface and groundwater, Tiruvallur District, Tamil Nadu, India. Applied Water Science 7(5): 2533-2544.

Kumarasinghe, K.M.S.M. and Rajapakse, R.R.G. R. (2013). Impact of anthropogenic activities on groundwater quality in Puttalam district. Journal of Geological Society of Sri Lanka 15: 129-135.

Kuruppuaracchchi, D.S.P. and Fernando W.A.R.N. (1999). Impact of agriculture on groundwater quality: leaching of fertilizers to groundwater in Kalpitiya Peninsula. Journal of Soil Science Society Sri Lanka 11: 9-15.

Melvani, K., Chandrasekera, K. and Mudannayake, R. (2006). The role of trees in the bioremediation of drinking water-Aresearch experiment in Nawakkaduwa, Kalpitiya, Proceedings of the $32^{\text {nd }}$ WEDC International Conference on Sustainable Development of Water Resources, Water Supply and Environmental Sanitation, 13-17 November. Colombo.

Molden, D.J., Amarasinghe, U.A. and Hussain, I. (2001). Water for rural development: Background paper on water for rural development prepared for the World Bank. Vol. 32. IWMI.

National Water Supply and Drainage Board. (2008). Report on Puttalam town water supplies wells. Puttalam, Sri Lanka, NWSDB, Colombo (unpublished).

Panabokke, C.R. and Perera, A.P.G.R.L. (2005). Groundwater resources of Sri Lanka. Water Resources Board, Colombo, Sri Lanka, 28.

Raicy, M.C., Parimala, R.S., Brindha, K. and Elango, L. (2012). Mitigation of seawater intrusion by managed aquifer recharge. In: L. Elango, V.C. Goyal, W. Thomas (Eds.), Managed Aquifer Recharge: Methods, Hydrogeological Requirements, Pre and Post-treatment Systems Pp. 83-99.

R Core Team. (2019). R: A language and environment for statistical computing. R Foundation for Statistical Computing, Vienna, Austria.

Tantrigoda, D.A. and Geekiyanage, P. (1991). An interpretation of gravity anomalies over the Andigama and Tabbowa sedimentary basins in north-west of Sri Lanka. Journal of the National Science Council of Sri Lanka 19(1): 39-51.

Toth, J. (1963). A theoretical analysis of groundwater flow in small drainage basins. Journal of geophysical research 68(16): 4795-4812. 
UNICEF. (2016). Retrieved from https://www.unicef.org/ environment/ (accessed on 16.12.2018).

Vacher, H.L. (1988). Dupuit-Ghyben-Herzberg analysis of strip-island lenses. Geological Society of America Bulletin 100(4): 580-591.

Water Resources Board. (2010). Groundwater database in Puttalam, Sri Lanka (unpublished).

Weerasinghe, W.A.R.H. and Jayasena, H.A.H. (2012). Hydraulic Property Variations in Sedimentary and Hard Rock Aquifers in Sri Lanka - Evaluations Based on Pumping Tests. Proceedings of the 28th Annual Sessions, 24th February 2012, GSSL, Sri Lanka, Pp. 7.

Wetselaar, R., Fox, J.J., Smith, G.D., Rum, A.M., Moermonto, R.J. and Ahmad, I. (1993). Groundwater nitrate in East Java, Indonesia. AGSO J. Geol. Geophy. 14.

WHO. (2018). Retrieved from https://www.who.int/ gho/publications /world health statistics/2018/en/ (accessed on 16.12.2018).

Wright, E.P. (1992). The hydrogeology of crystalline basement aquifers in Africa. In: E.P. Wright, and W.G. Burgess (Eds.), Hydrogeology of Crystalline Basement Aquifers in Africa, Geological Society Special Publication 66, Pp.1-27. 